Article

\title{
Effect of Heat Treatments on the Microstructural Evolution of a Single Crystal High-Entropy Superalloy
}

\author{
Takuma Saito ${ }^{1,2, *}$, Yung-Ta Chen ${ }^{3}$, Yuji Takata ${ }^{2}$, Kyoko Kawagishi ${ }^{4,5}$, Wei-Che Hsu ${ }^{3}$, \\ An-Chou Yeh ${ }^{3}$ and Hideyuki Murakami ${ }^{1,2}$ \\ 1 Department of Nanoscience and Nanoengineering, Waseda University, Tokyo 169-8555, Japan; \\ MURAKAMI.Hideyuki@nims.go.jp \\ 2 Research Center for Structural Materials, National Institute for Materials Science, \\ Tsukuba 305-0047, Japan; TAKATA.Yuji@nims.go.jp \\ 3 Department of Materials Science and Engineering, National Tsing Hua University, \\ Hsinchu 30013, Taiwan; henrychen22350@yahoo.com.tw (Y.-T.C.); \\ zzz800918@gmail.com (W.-C.H.); yehac@mx.nthu.edu.tw (A.-C.Y.) \\ 4 Superalloys and High Temperature Materials Group, Research Center for Structural Materials, \\ National Institute for Materials Science, Tsukuba 305-0047, Japan; \\ KAWAGISHI.Kyoko@nims.go.jp \\ 5 Department of Materials Science, Waseda University, Tokyo 169-8555, Japan \\ * Correspondence: SAITO.Takuma@nims.go.jp; Tel.: +81-909-302-0601
}

Received: 16 October 2020; Accepted: 24 November 2020; Published: 29 November 2020

check for updates

\begin{abstract}
The effect of solution heat treatment as well as primary and secondary aging treatment conditions on the microstructural evolution of a high-entropy superalloy was investigated. The as-cast sample shows coarsened $\gamma^{\prime}$ precipitates and other extra phases at interdendrite region due to microsegregation. This microsegregation makes $\gamma^{\prime}$ solvus unclear and decreases the solidus. After conducting the solution treatment determined in this study, primary aging conditions showing an aligned cubic $\gamma^{\prime}$ phase at $1050{ }^{\circ} \mathrm{C}$ for $4 \mathrm{~h}$ and random spherical $\gamma^{\prime}$ precipitates at $950{ }^{\circ} \mathrm{C}$ for $20 \mathrm{~h}$ in similar size were found. By using both samples, secondary aging conditions showing coarsened secondary $\gamma^{\prime}$ precipitates and $\gamma$ particles inside the $\gamma^{\prime}$ precipitates at $800{ }^{\circ} \mathrm{C}$ for $20 \mathrm{~h}$ and fine secondary $\gamma^{\prime}$ precipitates at 850 and $870{ }^{\circ} \mathrm{C}$ for $20 \mathrm{~h}$ were found.
\end{abstract}

Keywords: heat treatment; superalloy; microstructure; single crystal; gamma prime

\section{Introduction}

Recently, high-entropy alloys have attracted much attention for the development of new alloy systems [1,2]. Single phase alloys having a face-centered cubic (FCC) structure, such as NiCoCrFeMn, are reported to show excellent yield stress [3], work hardening [4], and fracture toughness [5], especially at cryogenic temperatures. On the other hand, such FCC-structured single phase alloys have not demonstrated reasonable mechanical properties such as yield stresses or creep ruptured lives at higher temperatures [3]. Historically, alloys that have $\mathrm{L}_{2}$ structured $\gamma^{\prime}$ precipitates in FCC-structured $\gamma$ matrix keeping coherency between them have been designed to exhibit superior mechanical properties to single phase alloys [6,7]. Therefore, for high temperature use, a number of Ni-based superalloys and Co-based superalloys have been proposed by applying the precipitation hardening concept of the $\gamma^{\prime}$ precipitates in the $\gamma$ matrix. To enhance mechanical properties of high-entropy alloys at higher temperature, a new alloy design concept, namely high-entropy superalloys (HESAs), was proposed in a manner similar to designing conventional Ni-based and Co-based superalloys [8] from the composition 
space of high-entropy alloys such as $\mathrm{Co}_{1.5} \mathrm{CrFeNi}_{1.5} \mathrm{Ti}_{0.5}$ [9] and $\mathrm{CoCrCuFeNiAl}$ [10]. Furthermore, nominal compositions of HESAs [11] are within the expanded definition of a high-entropy alloy, $\Delta S>1.5 R$, where $R$ is gas constant [12]. This concept successfully introduced a new series of HESAs that show excellent yield stress close to that of conventional Ni-based superalloys [13].

In order for $\gamma^{\prime}$ precipitation hardened alloys to possess excellent mechanical properties, the optimization of heat treatment as well as alloy compositions are critical since the heat treatment condition can control the shape [14], distribution [15], and size [16] of precipitates, which accordingly alters the operative deformation mechanisms and determines their mechanical properties [17-19]. However, the relationship between the heat treatment conditions and microstructure of HESAs has not been fully understood yet [20,21].

This study aims to develop the heat treatment and microstructure relationship of HESAs, whose microstructure is inherently similar to Ni-based single crystal superalloys used for elevated temperature applications such as turbine blades. Industrial Ni-based single crystal superalloys for turbine blades are generally subjected to a solution heat treatment followed by primary and secondary aging treatments. Therefore, effects of the solution treatment as well as the primary and secondary aging conditions on changes in size, shape, and distribution of $\gamma^{\prime}$ precipitates were focused on in comparison to those of conventional Ni-based single crystal superalloys because HESAs can be a candidate for materials of turbine blades.

\section{Materials and Methods}

\subsection{Single Crystal Casting}

The nominal composition of the HESA investigated in this study is listed in Table 1. It should be noted that this alloy has negligible carbon content, different to a previous study that reported the composition of its HESA having columnar crystal [20]. Since the HESA in this research was a single crystal, there is no need to add any grain boundary strengthening elements such as carbon.

Table 1. Composition of high-entropy superalloy (HESA) in this report (at. \%).

\begin{tabular}{cccccccccc}
\hline HESA & Ni & Co & Cr & Fe & Mo & W & Ti & Al & Nb \\
\hline Nominal composition & 48.0 & 16.9 & 7.5 & 8.9 & 0.9 & 0.5 & 5.8 & 10.3 & 1.2 \\
ICP-OES & 48.5 & 17.1 & 7.1 & 8.9 & 0.9 & 0.5 & 5.8 & 10.0 & 1.2 \\
\hline
\end{tabular}

Single crystal bars of the HESA were obtained by using a directional solidification furnace. Mixture of pure raw metal pellets with total weight of $2 \mathrm{~kg}$ was put into an $\mathrm{Al}_{2} \mathrm{O}_{3}$ crucible, then melted by high frequency induction heating. Later, the molten alloy was poured into a mold, which consists of eight cylindrical bars, and each of the bar was attached with a grain selector for single crystal growth. The mold, which was set on the copper chill plate, was pulled down from the heating chamber to the cooling chamber at the speed of $150 \mathrm{~mm} / \mathrm{h}$ so that the molten alloy can be directionally solidified. The mold was removed by a hammer and a sand blaster to obtain a cast bulk alloy. After the casting, single crystal bars of the HESA having a $11 \mathrm{~mm}$ diameter and a $140 \mathrm{~mm}$ length were obtained by cutting the bulk alloy with a precision cutting machine. Samples for heat treatment were taken from single crystal bars to have thickness of approximately $3 \mathrm{~mm}$.

To confirm the composition of the as-cast alloy, inductivity coupled plasma optical emission spectrometry (ICP-OES: ICP-OES 720-ES, Agilent, Santa Clara, CA, USA) was performed. A sample for ICP-OES was taken just below the selector part. Table 1 compares the nominal composition and the measured composition by ICP-OES, which are almost identical to each other.

\subsection{Heat Treatment}

All the heat treatments were performed in an electric furnace (MSFT-1520-P, NIKKATO, Osaka, Japan). For the solution treatment, samples were put into a quartz glass tube filled with 
an argon gas to prevent samples from oxidation. The argon gas pressure in the quartz glass tube was adjusted so that it reached 1 atmospheric pressure when the samples were heated to the solution treatment temperature. After the solution treatment, the samples confined in the quartz glass tube were air cooled to obtain finer $\gamma^{\prime}$ precipitates. Then, the samples were taken out by breaking the glass tube. The following primary and secondary aging treatments were conducted with the samples put on mullite crucibles in the muffle furnace exposed in air. Since the aging treatment temperatures are lower than the solution treatment temperature, oxidation of samples during the aging treatment is expected to be limited to the surface, and thus the heat treatment in air is acceptable. After the aging treatments, they were taken out from the furnace and cooled in air.

\subsection{Thermal Analysis}

To evaluate phase transition temperatures of the HESA, a differential thermal analysis (DTA: Labsys, SETARAM, Caluire et Cuire, France) was conducted for the as-cast and solution heat treated samples. Samples for the DTA analysis are in a cylindrical shape having a diameter of $3.2 \mathrm{~mm}$ and a height of $3.5 \mathrm{~mm}$. During the DTA analysis, the sample was heated at $40{ }^{\circ} \mathrm{C} / \mathrm{min}$ from 20 to $1000{ }^{\circ} \mathrm{C}$ followed by $5{ }^{\circ} \mathrm{C} / \mathrm{min}$ heating from 1000 to $1500{ }^{\circ} \mathrm{C}$ in flowing argon atmosphere.

\subsection{Microstructural Observation}

The samples were embedded into a phenolic resin, then mechanically polished using 320, 400, and 600 grit $\mathrm{SiC}$ paper, followed by a $3 \mu \mathrm{m}$ diamond slurry and $0.02 \mu \mathrm{m}$ colloidal silica. Samples for microstructural observation were electrochemically polished using a $20 \%$ phosphoric acid solution at the condition of $2.5 \mathrm{~V}$. Microstructure of samples was observed by a scanning electron microscope (SEM: JSM-7200, JEOL, Tokyo, Japan) with the accelerating voltage of 15 or $20 \mathrm{kV}$. To avoid some regions possibly affected by oxidation, the central region of the samples was observed. For as-cast samples, compositions of phases at an interdendrite region were analyzed by an electron probe microanalyzer (EPMA: JXA-8500F, JEOL, Tokyo, Japan).

\section{Results and Discussion}

\subsection{As-Cast Sample}

Some symbolic microstructures observed in the as-cast sample are displayed in Figure 1. Since the heat-treated HESA was reported to have $\gamma$ and $\gamma^{\prime}$ two-phase structure [20], the variety of microstructure shown in Figure 1 indicates inhomogeneity of alloying element distribution. In Figure 1a, some brightly contrasted precipitate-like regions are observed in the interdendrite zones. The magnified image of the bright region is shown in Figure $1 b$, indicating that this region consisted of some extra phases different to the $\gamma$ and $\gamma^{\prime}$ phases, which were observed in the dendrite-core region shown in Figure 1d,e. Furthermore, coarsened $\gamma^{\prime}$ precipitates in the $\gamma$ matrix were also found in the interdendrite region, as shown in Figure 1c. These types of segregation, such as the extra phases and the coarsened $\gamma^{\prime}$ precipitates at the interdendrite region, are called microsegregation.

To further identify phases at the interdendrite region shown in Figure $1 \mathrm{~b}$, a composition analysis using EPMA was performed. Since the size of the $\gamma$ matrix channel in the as-cast sample was smaller than the spatial resolution of EPMA (approximately $1 \mu \mathrm{m}$ ), the composition analysis for the $\gamma$ matrix channel was not conducted. For each phase, at least 5 points were measured, and then its composition was determined by taking an average of the compositions measured. Compositions of phases are listed in Table 2. Phases A, B, and C have different compositions from that of D, which can be regarded as the $\gamma^{\prime}$ precipitates at the interdendrite region. Moreover, the Ti content in phases $\mathrm{A}$ and $\mathrm{C}$, and the $\mathrm{Nb}$ content in phase B are higher than those in phase $\mathrm{D}$. This indicates that phases $\mathrm{A}, \mathrm{B}$, and $\mathrm{C}$ cannot be assigned as $\gamma$ phase. Ti and $\mathrm{Nb}$ are $\gamma^{\prime}$ former elements, and thus their contents in phases $\mathrm{A}, \mathrm{B}$, and $\mathrm{C}$ should be much lower than those in phase $D$, if these phases were $\gamma$. For these reasons, these phases should be different from $\gamma$ and $\gamma^{\prime}$ phases. These extra phases should disappear by performing an 
appropriate solution treatment, which accordingly leads to a desired microstructure having only $\gamma$ and $\gamma^{\prime}$ phases. In addition, coarsened $\gamma^{\prime}$ precipitates such as $\mathrm{D}$ are not feasible for strength. As shown in Figure 1c, coarsened $\gamma^{\prime}$ precipitates are distributed in the interdendrite region. On the other hand, fine $\gamma^{\prime}$ precipitates appear in the dendrite-core region as shown in Figure 1d,e. To obtain higher mechanical strength, such fine $\gamma^{\prime}$ precipitates should be uniformly distributed over the whole region. Thus, post heat treatments are essential for the cast HESA.

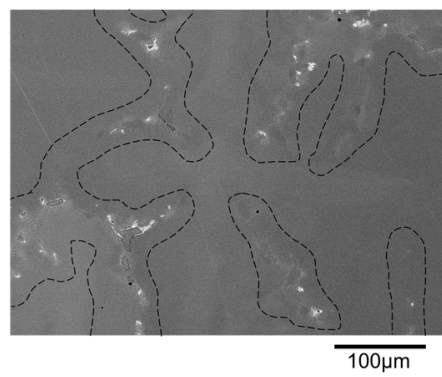

(a)

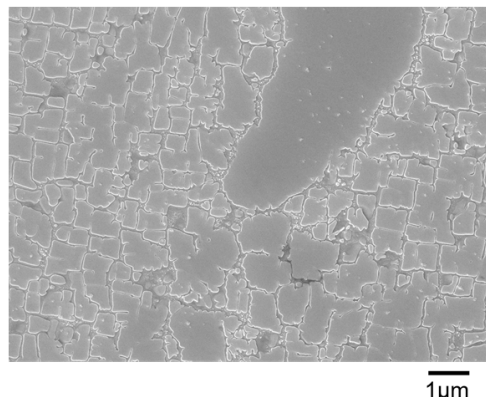

(c)

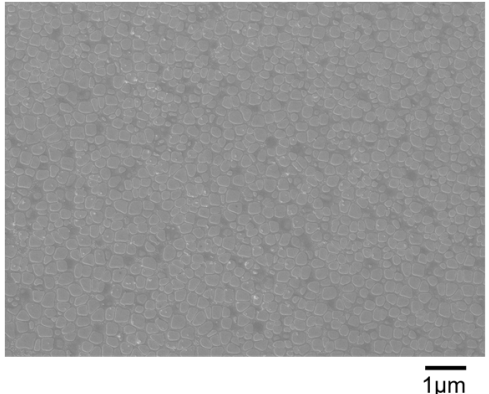

(d)

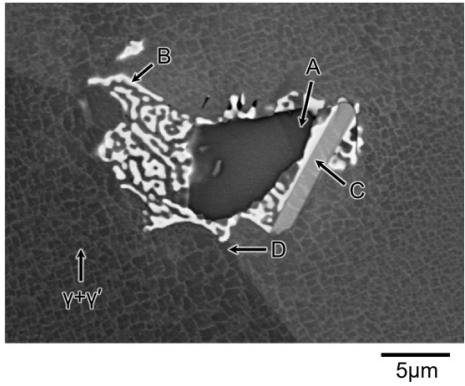

(b)

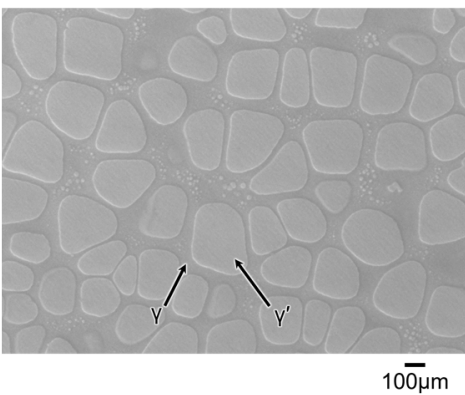

(e)

Figure 1. Microstructure in the as-cast sample. (a) Microstructure at lower magnification in back-scattered electron image, where the regions surrounded by black dot lines indicate an interdendrite region; (b) Phases at the interdendrite region for point analysis in a backscattered electron image obtained by an electron probe microanalyzer (EPMA), indicated by black arrows; (c) $\gamma$ matrix and coarsened $\gamma^{\prime}$ precipitates at interdendrite region in secondary electron image; (d) $\gamma$ matrix and fine $\gamma^{\prime}$ precipitates at dendrite-core region in secondary electron image; (e) $\gamma$ matrix and fine $\gamma^{\prime}$ precipitates at dendrite-core region in secondary electron image at higher magnification of Figure 1d.

Table 2. Compositions of the phases present in the interdendrite region shown in Figure $1 \mathrm{~b}$ in the as-cast sample obtained by an electron probe microanalyzer (EPMA) (at. \%).

\begin{tabular}{cccccccccc}
\hline Analyzed Phase & $\mathbf{N i}$ & $\mathbf{C o}$ & $\mathbf{C r}$ & $\mathbf{F e}$ & $\mathbf{M o}$ & $\mathbf{W}$ & $\mathbf{T i}$ & $\mathbf{A l}$ & $\mathbf{N b}$ \\
\hline A & 38.7 & 15.8 & 3.6 & 4.5 & 0.3 & $<0.1$ & 12.7 & 20.4 & 4.1 \\
B & 24.0 & 23.2 & 13.1 & 11.9 & 3.9 & 0.3 & 6.4 & 3.7 & 13.5 \\
C & 49.2 & 18.5 & 3.4 & 5.3 & 0.7 & 0.3 & 10.9 & 5.3 & 6.5 \\
D & 48.5 & 16.1 & 4.9 & 6.2 & 0.9 & 0.2 & 9.5 & 9.5 & 4.3 \\
\hline
\end{tabular}

\subsection{Solution Treatment}

Solution treatment conditions should be carefully determined because the interdendrite region where extra phases and the coarsened $\gamma^{\prime}$ precipitates are observed could become a site for incipient melting. Therefore, if a solution heat treatment is conducted at temperatures that are higher than that incipient melting, this will lead to the coarsening of $\gamma^{\prime}$ precipitates and eutectic 
phases at the interdendrite region, thereby deteriorating mechanical properties. On the other hand, to realize more homogenized microstructure, the solution treatment should be performed within the temperature range where $\gamma$ single phase exists. Based on the phase diagram, a solution treatment should be performed within the temperatures that are higher than the $\gamma^{\prime}$ solvus and lower than the solidus, termed as heat-treatment window.

To avoid incipient melting, two types of solution heat treatments were examined, i.e., a slope-like solution treatment [22] and the stepwise solution treatment. In the slope-like solution treatment, alloys are continuously heated without temperature holding stages. Instead, the three-step heating rate was applied, that is, it was heated approximately at $8^{\circ} \mathrm{C} / \mathrm{min}$ until $1100{ }^{\circ} \mathrm{C}$ (below the $\gamma^{\prime}$ solvus temperature), then heated at $0.4{ }^{\circ} \mathrm{C} / \mathrm{min}$ up to $1160{ }^{\circ} \mathrm{C}$ followed by $0.067^{\circ} \mathrm{C} / \mathrm{min}$ up to $1230{ }^{\circ} \mathrm{C}$ to avoid incipient melting. On the other hand, the stepwise solution treatment is generally used in industry, where the time versus temperature plot looks like steps. Samples are heated at a certain temperature for certain time then further heated for the second step. Solution treatments that were examined in this study are listed in Table 3, and the corresponding microstructure after each solution treatment is shown in Figure 2, respectively.

Table 3. Solution treatment conditions.

\begin{tabular}{cccc}
\hline Type & No. & Procedure & Incipient Melting \\
\hline Slope & 1 & R.T. $\rightarrow\left(\begin{array}{c}2.5 \mathrm{~h}) \rightarrow 1100^{\circ} \mathrm{C} \rightarrow(2.5 \mathrm{~h}) \rightarrow 1160^{\circ} \mathrm{C} \\
\rightarrow(17.5 \mathrm{~h}) \rightarrow 1230^{\circ} \mathrm{C} \rightarrow \text { A.Q. }\end{array}\right.$ & No \\
\hline & 1 & R.T. $\rightarrow(2.0 \mathrm{~h}) \rightarrow 1150^{\circ} \mathrm{C} / 2 \mathrm{~h} \rightarrow(0.5 \mathrm{~h}) \rightarrow 1210^{\circ} \mathrm{C} / 5 \mathrm{~h} \rightarrow$ A.Q. & No \\
Step & 2 & R.T. $\rightarrow(2.0 \mathrm{~h}) \rightarrow 1175^{\circ} \mathrm{C} / 2 \mathrm{~h} \rightarrow(0.5 \mathrm{~h}) \rightarrow 1215^{\circ} \mathrm{C} / 5 \mathrm{~h} \rightarrow$ A.Q. & No \\
& 3 & R.T. $\rightarrow(2.0 \mathrm{~h}) \rightarrow 1200^{\circ} \mathrm{C} / 2 \mathrm{~h} \rightarrow(0.5 \mathrm{~h}) \rightarrow 1230^{\circ} \mathrm{C} / 5 \mathrm{~h} \rightarrow$ A.Q. & Yes \\
& 4 & R.T. $\rightarrow(2.0 \mathrm{~h}) \rightarrow 1230^{\circ} \mathrm{C} / 2 \mathrm{~h} \rightarrow(0.5 \mathrm{~h}) \rightarrow 1260^{\circ} \mathrm{C} / 5 \mathrm{~h} \rightarrow$ A.Q. & Yes \\
\hline
\end{tabular}

R.T. and A.Q. are short for room temperature and air quench, respectively.

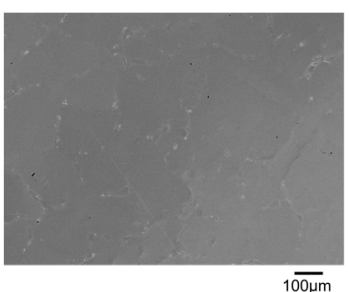

(a)

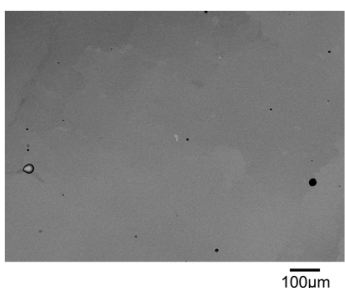

(e)

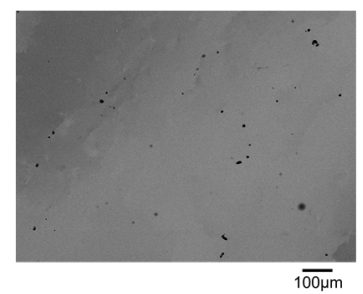

(b)

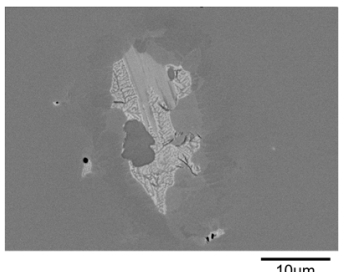

(f)

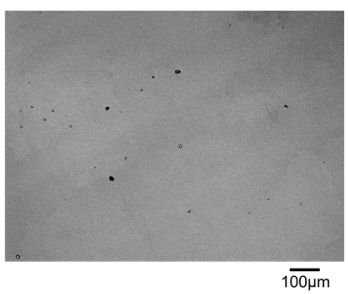

(c)

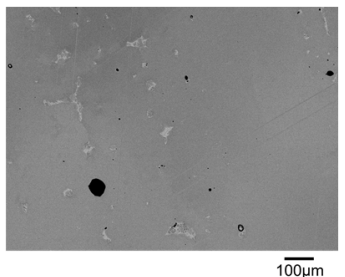

(g)

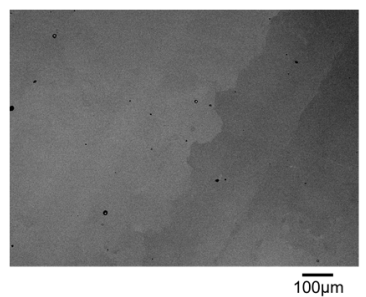

(d)

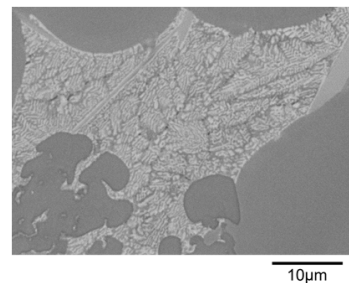

(h)

Figure 2. Microstructure of the as-cast and solution heat treated samples in backscattered electron modes. (a) As-cast, (b) Slope 1, (c) Step 1, (d) Step 2, (e,f) Step 3, (g,h) Step 4.

Microstructures after Slope 1, Step 1, and Step 2 consist of the $\gamma$ matrix and $\gamma^{\prime}$ precipitates without any extra phases, as shown in Figure $2 b-d$. On the other hand, the Step 3 treated sample shows some inhomogeneous microstructure, although the maximum heat treatment temperature of $1230{ }^{\circ} \mathrm{C}$ is the same as that of the Slope 1 treatment. This indicates that a long, slow increase in heating temperature 
from 1160 to $1230{ }^{\circ} \mathrm{C}$ for the Slope 1 treatment can offer time for the extra phases to dissolve into the $\gamma$ matrix before incipient melting starts. On the other hand, in the Step 3 treatment, heating duration at $1200{ }^{\circ} \mathrm{C}$ for $2 \mathrm{~h}$ followed by a short time temperature increase from 1200 to $1230{ }^{\circ} \mathrm{C}$ for $0.5 \mathrm{~h}$ is not long enough for the extra phases to dissolve into the $\gamma$ matrix, and incipient melting starts as shown in Figure 2e,f. Higher heating steps by the Step 4 treatment gave rise to the more significant incipient melting as shown in Figure 2g,h.

To confirm the effect of microsegregation on the phase transition kinetics of the HESA, a DTA analysis was performed for the as-cast (AC) and the Step 2 (S2) treated samples. The weight of AC sample was $196.9 \mathrm{mg}$, and on the other hand, that of the S2 sample was $194.8 \mathrm{mg}$, respectively. Figure 3 shows the heat flow curves as a function of temperature, obtained by the DTA analysis. Two notable differences were found in the heat flow curves of the AC and S2-treated samples. The first point is the clear increase of heat flow from around 1160 to $1182{ }^{\circ} \mathrm{C}$ observed in the S2 sample; on the other hand, such a clear increase in heat flow was not observed in the AC sample.

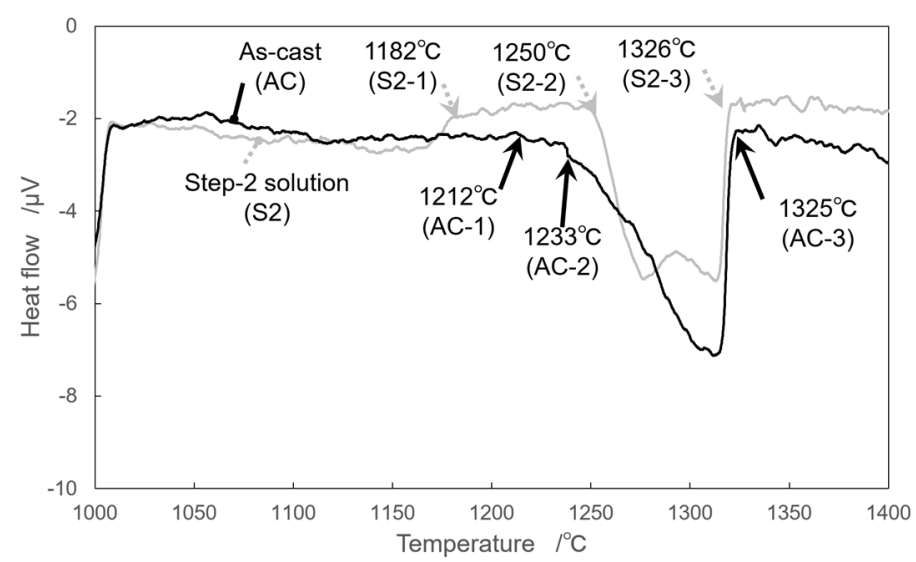

Figure 3. Heat flow chart of the as-cast (AC) and Step 2 (S2) samples obtained by a differential thermal analysis (DTA).

From the shape of the heat flow curve of the S2 sample, the increase in heat flow up to $1182^{\circ} \mathrm{C}$, assigned as S2-1, is regarded as the end of the endothermic reaction during heating, indicating the complete dissolution of the $\gamma^{\prime}$ precipitates into the $\gamma$ matrix. It is thus concluded that the $\gamma^{\prime}$ solvus temperature of the HESA having a homogeneous microstructure without coarsened $\gamma^{\prime}$ precipitates and extra phases at the interdendrite region is around $1182^{\circ} \mathrm{C}$. The $\gamma^{\prime}$ solvus temperature in this study is slightly lower than the previously reported value of $1199{ }^{\circ} \mathrm{C}$ [13]. On the other hand, as shown in Figure 1, the AC sample exhibited inhomogeneity of microstructure, showing a clear difference between the interdendrite and the dendrite core region. Furthermore, the extra phases having different compositions other than those of the $\gamma$ matrix and the $\gamma^{\prime}$ precipitates are observed due to the microsegregation of constituent elements. These results indicate that there also exists compositional inhomogeneity of the $\gamma^{\prime}$ precipitates due to the microsegregation of constituent elements. This should lead to the variation in dissolution temperature of the $\gamma^{\prime}$ phase depending on the regions, which might result in the disappearance of a typical endothermic reaction around the $\gamma^{\prime}$ solvus temperature in the AC sample.

The second clear difference was found at the onset points of a large endothermic reaction, which refers to the starting point of melting. The heat flow curve of the S2 sample shows the sudden drop around $1250^{\circ} \mathrm{C}$ (referred to as S2-2), which can be assigned as the incipient melting temperature. This temperature at the incipient melting of the $\mathrm{S} 2$ sample could be regarded as the solidus of the HESA because the microstructure of the S2 sample is more homogeneous without microsegregation, which causes the coarsened $\gamma^{\prime}$ phase and extra phases in the interdendrite region, than that of the AC sample. On the other hand, the heat flow curve of the AC sample starts to drop from $1212^{\circ} \mathrm{C}(\mathrm{AC}-1)$, and then the drop accelerates from $1233^{\circ} \mathrm{C}$, at the point of AC-2. In addition, AC-1 and AC-2 are lower 
than the onset point of S2 (S2-2), which indicates that in the AC sample, incipient melting starts to occur at $\mathrm{AC}-1$, in the interdendrite region including the coarsened $\gamma^{\prime}$ precipitates and extra phases. Further, a gradual decrease of heat flow for the AC sample from AC-1 to AC-2 indicates that the fraction of the incipient melting region at the interdendrite region is small. Interestingly, the offset point of melting is almost the same between the AC sample at AC-3 $\left(1326{ }^{\circ} \mathrm{C}\right)$ and the S2 sample at S2-3 $\left(1325{ }^{\circ} \mathrm{C}\right)$. This result may be attributed to the uniform distribution of the solute elements at the end of melting. In [23], in a Ni-based single crystal superalloy CMSX-10K by using a differential scanning calorimetry (DSC) analysis, as-cast alloys having microsegregation was also reported to have a lower incipient melting temperature than solution-treated alloys having a homogeneous microstructure.

The solvus of the $\gamma^{\prime}$ phase, the solidus, and the liquidus temperatures obtained by the DTA analysis of the S2 sample were compared with those derived from CALPHAD (CALculation of PHAse Diagram) methods, i.e., Thermo Calc software (Thermo-Calc 2020b, Thermo-Calc software, Solna, Sweden) using TCNI8 and TCHEA4 databases, which are respectively optimized for Ni-based superalloys and high-entropy alloys. Simulation of CALPHAD does not include the effect of segregation of constituent elements, and therefore, DTA results of more homogenized sample, such as the S2 sample, should be used to compare results simulated by CALPHAD. Table 4 summarizes the results obtained by the DTA analysis and simulated by CALPHAD. In the present study, simulation results based on TCNI8 shows closer values than those based on TCHEA4, suggesting that for phase constitution simulation, using the TCNI8 database is more suitable for HESAs than using TCHEA4.

Table 4. Phase transition temperatures obtained by DTA and CALPHAD simulation.

\begin{tabular}{|c|c|c|c|c|c|c|c|}
\hline Alloys & Method & $\begin{array}{l}\text { Solution } \\
\text { Conditions }\end{array}$ & $\begin{array}{c}\text { Solvus of } \gamma^{\prime} \\
\text { Phase } /{ }^{\circ} \mathrm{C}\end{array}$ & $\begin{array}{c}\text { Incipient Melting } \\
\text { Temperature } \\
/{ }^{\circ} \mathrm{C}\end{array}$ & $\begin{array}{l}\text { Solidus } \\
\qquad /{ }^{\circ} \mathrm{C}\end{array}$ & $\begin{array}{l}\text { Liquidus } \\
\qquad /{ }^{\circ} \mathrm{C}\end{array}$ & $\begin{array}{l}\text { Heat Treatment } \\
\text { Window } /{ }^{\circ} \mathrm{C}\end{array}$ \\
\hline \multirow{4}{*}{ HESA } & DTA & As-cast & Unclear & 1212 & - & 1325 & - \\
\hline & DTA & Step-2 & 1182 & 1250 & 1250 & 1326 & 68 \\
\hline & $\begin{array}{c}\text { ThermoCalc } \\
\text { (TCNI8) }\end{array}$ & - & 1173 & - & 1235 & 1313 & 62 \\
\hline & $\begin{array}{l}\text { ThermoCalc } \\
\text { (TCHEA4) }\end{array}$ & - & 1161 & - & 1212 & 1309 & 51 \\
\hline SRR99 & $\begin{array}{c}\text { ThermoCalc } \\
\text { (TCNI8) }\end{array}$ & - & 1239 & - & 1325 & 1371 & 86 \\
\hline CMSX-2 & $\begin{array}{c}\text { ThermoCalc } \\
\text { (TCNI8) }\end{array}$ & - & 1281 & - & 1341 & 1378 & 60 \\
\hline CMSX-4 & $\begin{array}{l}\text { ThermoCalc } \\
\text { (TCNI8) }\end{array}$ & - & 1263 & - & 1342 & 1388 & 79 \\
\hline CMSX-10 & $\begin{array}{l}\text { ThermoCalc } \\
\text { (TCNI8) }\end{array}$ & - & 1371 & - & 1385 & 1428 & 14 \\
\hline
\end{tabular}

Using ThermoCalc software with the TCNI8 database, the solvus of the $\gamma^{\prime}$ phase, the solidus, and the liquidus temperatures of some conventional Ni-based single crystal superalloys were predicted and are also summarized in Table 4 . The solvus of the $\gamma^{\prime}$ phase, the solidus, and the liquidus of the HESA are all lower than those of SRR99 [24], CMSX-2 [25], CMSX-4 [26], and CMSX-10 [27], whereas the heat treatment window of the HESA, determined by the difference between the solvus of the $\gamma^{\prime}$ phase and the solidus, is almost comparable to the first generation superalloy CMSX-2. This also indicates that a careful solution heat treatment is important for HESA to obtain a homogenized microstructure without any localized melting.

From these results, it is concluded that the homogenization of the cast single-crystal HESA was successful under the Slope 1, Step 1, and Step 2 heat-treatment conditions, and we confirmed that all these heat treatments were conducted within the range of the solution heat treatment window of the HESA, while some inhomogeneity in the microstructure of the as-cast sample would lead to the incipient melting below the solidus points. In the present study, the Slope 1 treatment was selected for the subsequent aging treatments. The microstructure after Slope 1 is shown in Figure 4 . Fine $\gamma^{\prime}$ precipitates, whose diameter is approximately $0.1 \mu \mathrm{m}$, are homogeneously distributed in the whole 
region of the sample in both the dendrite-core and the interdendrite regions. The extra phases or the coarsened $\gamma^{\prime}$ precipitates at the interdendrite region were not observed.

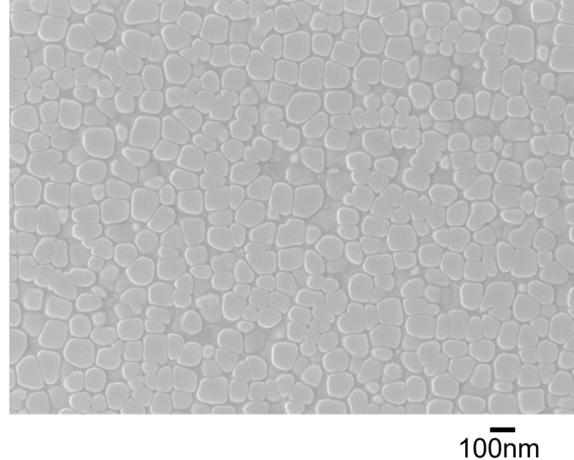

(a)

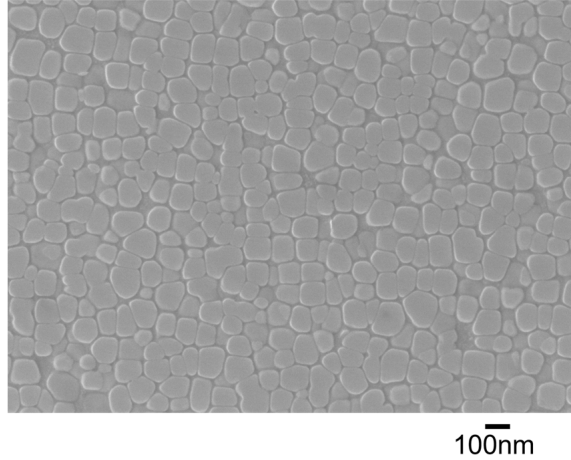

(b)

Figure 4. Microstructure after the Slope 1 solution treatment in the secondary electron images: (a) dendrite-core region and (b) interdendrite region.

\subsection{Primary Aging Treatment}

For conventional Ni-based single crystal superalloys as materials for turbine blades, a two-step aging treatment is generally conducted to control the size, shape, and distribution of $\gamma^{\prime}$ precipitates. Similar two-step aging treatments were conducted for the solution heat-treated HESA after Slope 1 to understand the heat treatment condition and microstructure relationship.

As a primary aging, a series of heat treatments were performed at 800,950 , and $1050{ }^{\circ} \mathrm{C}$ for 4 , 20, 100, 200, and $500 \mathrm{~h}$. Figure 5 displays variation of the microstructure after the series of primary aging treatments. Further, magnified microstructures of samples aged for 4 and $500 \mathrm{~h}$ are also shown in Figure 6.

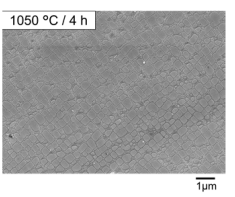

(a)

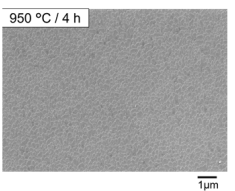

(f)

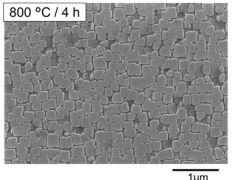

$(\mathbf{k})$

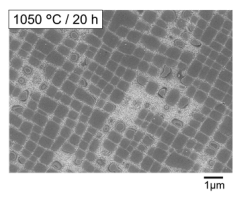

(b)

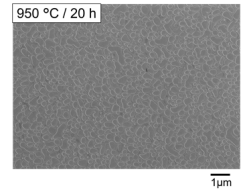

(g)

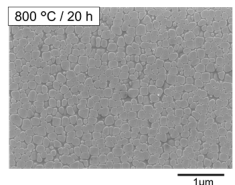

(1)

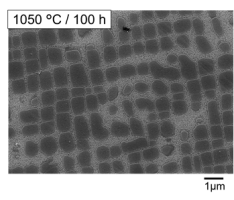

(c)

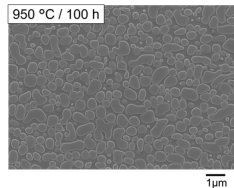

(h)

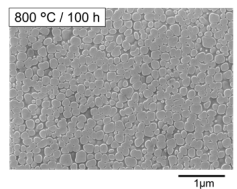

$(\mathbf{m})$

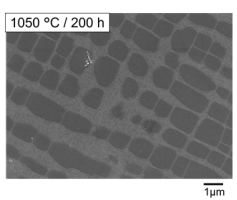

(d)

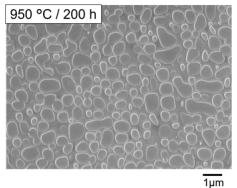

(i)

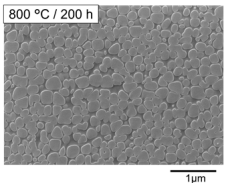

(n)

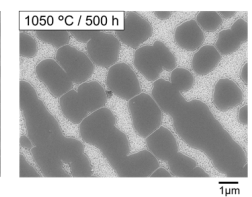

(e)

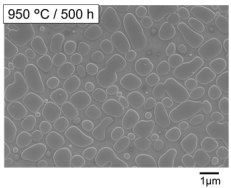

(j)

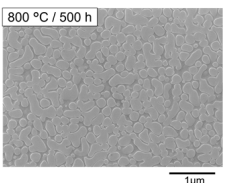

(o)

Figure 5. Microstructure after series of primary aging conditions following the Slope 1 solution treatment in secondary electron images at the dendrite-core region: $(\mathbf{a}-\mathbf{e})$ at $1050{ }^{\circ} \mathrm{C},(\mathbf{f}-\mathbf{j})$ at $950{ }^{\circ} \mathrm{C}$, $(\mathbf{k}-\mathbf{o})$ at $800{ }^{\circ} \mathrm{C},(\mathbf{a}, \mathbf{f}, \mathbf{k})$ for $4 \mathrm{~h},(\mathbf{b}, \mathbf{g}, \mathbf{l})$ for $20 \mathrm{~h},(\mathbf{c}, \mathbf{h}, \mathbf{m})$ for $100 \mathrm{~h},(\mathbf{d}, \mathbf{I}, \mathbf{n})$ for $200 \mathrm{~h},(\mathbf{e}, \mathbf{j}, \mathbf{o})$ for $500 \mathrm{~h}$ in primary aging conditions. 


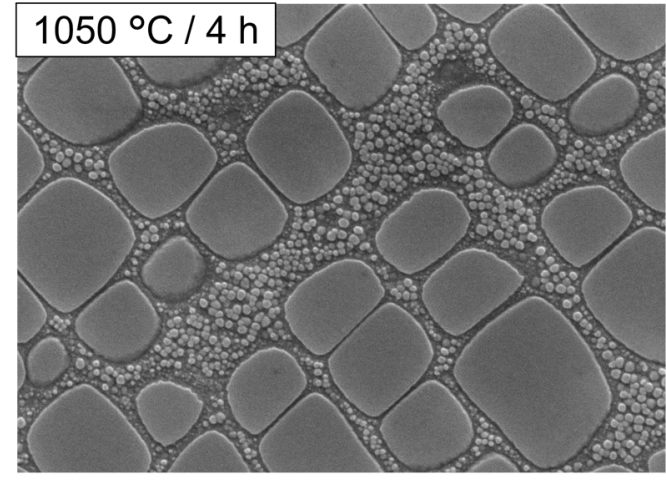

$10 \overline{n m}$

(a)

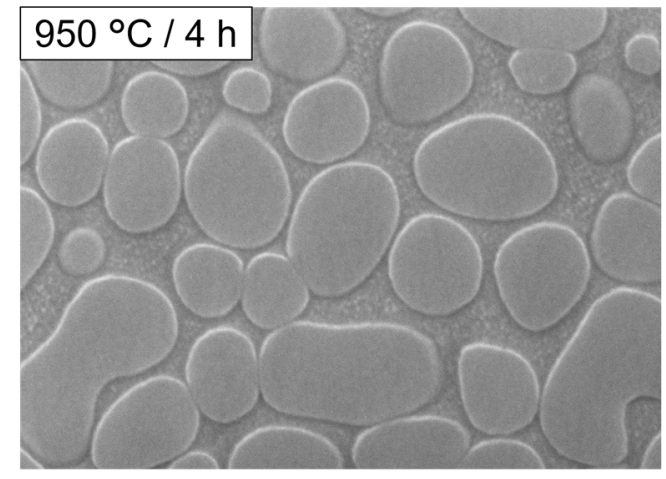

$10 \overline{0} \mathrm{~nm}$

(c)

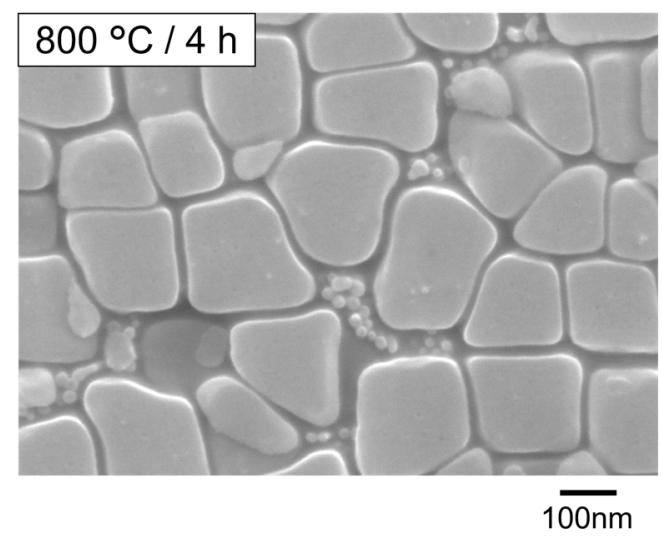

(e)

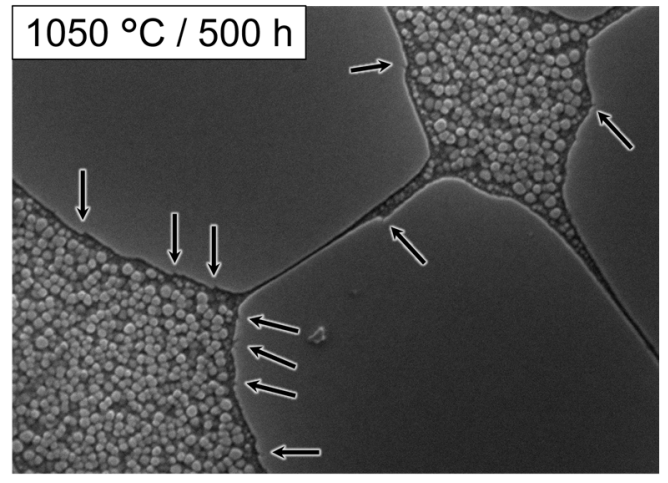

$10 \overline{n m}$

(b)

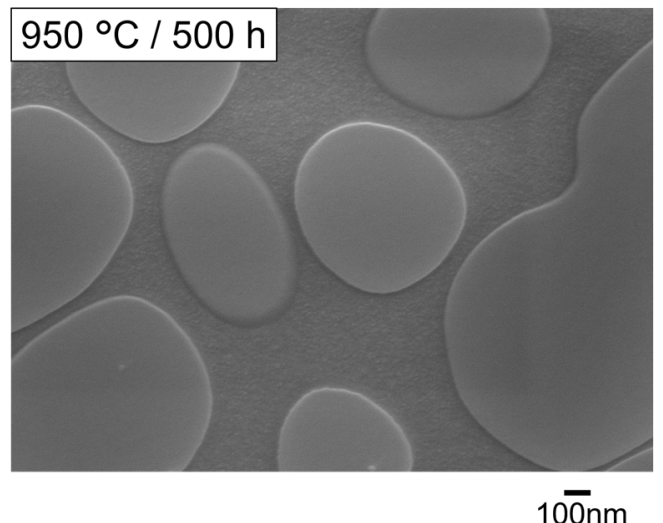

(d)

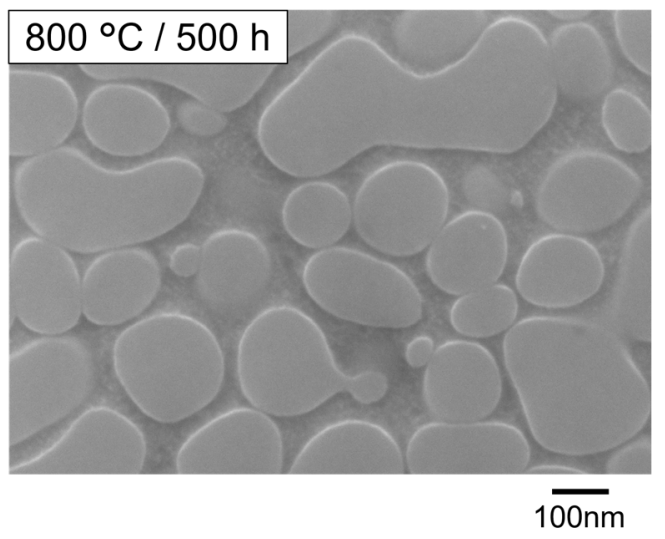

(f)

Figure 6. Magnified secondary electron images of samples at the dendrite-core region, selected from Figure 5: (a,b) at $1050{ }^{\circ} \mathrm{C},(\mathbf{c}, \mathbf{d})$ at $950{ }^{\circ} \mathrm{C},(\mathbf{e}, \mathbf{f})$ at $800^{\circ} \mathrm{C},(\mathbf{a}, \mathbf{c}, \mathbf{e})$ for $4 \mathrm{~h},(\mathbf{b}, \mathbf{d}, \mathbf{f})$ for $500 \mathrm{~h}$ in primary aging conditions. Black arrows in (b) show clear steps at $\gamma / \gamma^{\prime}$ interface.

Table 5 summarizes the microstructural features of the aged samples, focusing on the shape and distribution of primary $\gamma^{\prime}$ precipitates, and the size of the secondary $\gamma^{\prime}$ precipitates. It should be noted that nanosized $\gamma$ particles inside the primary $\gamma^{\prime}$ precipitates are not clearly observed here. 
Table 5. Summary of microstructural characters after primary aging following the Slope 1 solution treatment.

\begin{tabular}{|c|c|c|c|c|c|}
\hline \multirow{2}{*}{ Temperature/ ${ }^{\circ} \mathrm{C}$} & \multirow{2}{*}{ Type of Phase } & \multicolumn{4}{|c|}{ Time/h } \\
\hline & & 20 & 100 & 200 & 500 \\
\hline \multirow{3}{*}{1050} & $\begin{array}{l}\text { Primary } \gamma^{\prime} \\
\text { precipitates }\end{array}$ & \multicolumn{2}{|c|}{ Cube/aligned } & \multicolumn{2}{|c|}{ Directional cube/aligned } \\
\hline & $\begin{array}{c}\text { Secondary } \gamma^{\prime} \\
\text { precipitates }\end{array}$ & \multicolumn{4}{|c|}{ Fine (approximately $40 \mathrm{~nm}$ in diameter) } \\
\hline & Nano $\gamma$ particles & \multicolumn{4}{|c|}{ No } \\
\hline \multirow{3}{*}{950} & $\begin{array}{l}\text { Primary } \gamma^{\prime} \\
\text { precipitates }\end{array}$ & \multicolumn{4}{|c|}{ Sphere/random } \\
\hline & $\begin{array}{c}\text { Secondary } \gamma^{\prime} \\
\text { precipitates }\end{array}$ & \multicolumn{4}{|c|}{ Fine (approximately $10 \mathrm{~nm}$ in diameter) } \\
\hline & Nano $\gamma$ particles & \multicolumn{4}{|c|}{ No } \\
\hline \multirow{3}{*}{800} & $\begin{array}{l}\text { Primary } \gamma^{\prime} \\
\text { precipitates }\end{array}$ & Cube/random & Trans & andom & Sphere/random \\
\hline & $\begin{array}{c}\text { Secondary } \gamma^{\prime} \\
\text { precipitates }\end{array}$ & Coarsened & (approxi & $\begin{array}{l}\text { ned }+\mathrm{H} \\
10 \mathrm{~nm}\end{array}$ & ameter) \\
\hline & Nano $\gamma$ particles & \multicolumn{4}{|c|}{ No } \\
\hline
\end{tabular}

\subsubsection{Morphology of Primary $\gamma^{\prime}$ Precipitates}

As shown in Figure 4, after the Slope 1 solution treatment, randomly distributed and cubic-shaped fine $\gamma^{\prime}$ precipitates appear over the whole region. By the primary aging at $800{ }^{\circ} \mathrm{C}$, the $\gamma^{\prime}$ precipitates with random distribution gradually change their shape with increasing aging time, i.e., from a cubic to spherical shape, as shown in Figure 4a to Figure 5k-o. By the primary aging at $950{ }^{\circ} \mathrm{C}, \gamma^{\prime}$ precipitates change their shape from cubic to spherical even for $4 \mathrm{~h}$ of aging, more quickly than aged at $800{ }^{\circ} \mathrm{C}$, Figure $4 \mathrm{a}$ to Figure $5 \mathrm{f}$. With increasing aging time, the spherical $\gamma^{\prime}$ precipitates continue to grow while keeping their morphology, as shown in Figure $5 \mathrm{f}-\mathrm{j}$. This morphological change of the $\gamma^{\prime}$ precipitates from cubic to spherical shape, which was observed for the long-term aging for $500 \mathrm{~h}$ at $800^{\circ} \mathrm{C}$ or from the early stage of aging for $4 \mathrm{~h}$ at $950^{\circ} \mathrm{C}$, can be explained by the change in a lattice misfit between the $\gamma$ and $\gamma^{\prime}$ phases around these temperatures. The lattice misfit is defined by $\delta=\frac{a_{\gamma^{\prime}}-a_{\gamma}}{a_{\gamma}}$, where $a_{\gamma^{\prime}}$ and $a_{\gamma}$ are lattice parameters of $\gamma^{\prime}$ and $\gamma$ phases, respectively.

The lattice misfit at this temperature range between 800 and $950{ }^{\circ} \mathrm{C}$ is close to zero under near equilibrium condition. Given that coherent $\gamma^{\prime}$ precipitates with a small lattice parameter difference to the $\gamma$ matrix, spherical $\gamma^{\prime}$ precipitates should provide the lowest total free energy in the alloy system because under such condition, the free energy of the surface is more dominant in total free energy than that of the elastic strain energy caused by the lattice misfit [28].

On the other hand, when the primary aging was conducted at $1050^{\circ} \mathrm{C}$, the $\gamma^{\prime}$ precipitates with cubic shape started to align from $4 \mathrm{~h}$ of aging time as shown in Figure $5 \mathrm{a}$, and then the aligned distributed cubic $\gamma^{\prime}$ precipitates continued to grow up to $100 \mathrm{~h}$ of aging time, as shown in Figure 5a-c. This indicates that the lattice misfit moved toward the negative direction with increasing aging temperature, i.e., around zero between 800 and $950{ }^{\circ} \mathrm{C}$ to a negative value at $1050{ }^{\circ} \mathrm{C}$, because the thermal expansion coefficient of the $\gamma$ phase is larger than that of the $\gamma^{\prime}$ phase in Ni-based superalloys, in almost all the cases [29]. When the coherent elastic stress exists around the $\gamma^{\prime}$ precipitates by the presence of the lattice misfit, the free energy caused by the elastic stress becomes more dominant in the total free energy of the alloy system, thereby the $\gamma^{\prime}$ precipitates start to become cubic in shape [28]. Furthermore, the cubic $\gamma^{\prime}$ precipitates show aligned distribution from the view of elastic interaction energy [30]. On the other hand, the $\gamma^{\prime}$ precipitates start to show directional coarsening for a further aging time of 200 h, as shown in Figure 5d,e. Furthermore, there are a number of step-like $\gamma / \gamma^{\prime}$ interfaces observed, as indicated by black arrows in Figure 6b. These steps suggest the existence of interfacial dislocations, which could suppress the growth of $\gamma^{\prime}$ precipitates and thereby decrease 
the coherent elastic stress caused mainly by the lattice misfit [31]. At the same time, a straight $\gamma / \gamma^{\prime}$ interface on the possible merging side does not have step-like morphology. This indicates that the merger of the $\gamma^{\prime}$ precipitates could be accelerated by the coherent $\gamma / \gamma^{\prime}$ interface. Therefore, random directional coarsening of the $\gamma^{\prime}$ precipitates during aging without load might be formed by an anisotropic accumulation of dislocations at coherent $\gamma / \gamma^{\prime}$ interfaces, similar to the formation mechanism of rafted structure in deformation-induced samples after long-term aging without load at higher temperature [32,33].

From these experiments, the lattice misfit of the HESA is assumed to be zero around 800 and $950{ }^{\circ} \mathrm{C}$ and start to be negatively larger with increasing temperature from $950{ }^{\circ} \mathrm{C}$. This is a unique character for HESAs as a $\gamma^{\prime}$ precipitation hardening alloy. By utilizing such temperature dependence of the lattice misfit, the two contrasting types of microstructure can be obtained in the alloy with the same composition: a random distribution of spherical $\gamma^{\prime}$ precipitates and an aligned distribution of cubic $\gamma^{\prime}$ precipitates. In the present study, two types of samples are further focused on: (a) a heat-treated one at $950{ }^{\circ} \mathrm{C}$ for $20 \mathrm{~h}$, showing random distribution of spherical $\gamma^{\prime}$ precipitates (named as $\mathrm{S}$ condition) and having a diameter of approximately $0.30 \mu \mathrm{m}$; and (b) one at $1050^{\circ} \mathrm{C}$ for $4 \mathrm{~h}$, showing aligned distribution of cubic $\gamma^{\prime}$ precipitates (named as $C$ condition), having an edge length of approximately $0.35 \mu \mathrm{m}$. Both samples have similar $\gamma^{\prime}$ size.

Similar trend in microstructural change has been reported in some conventional Ni-based single crystal superalloys, such as SRR99 and CMSX-2. SRR99 showed a very similar microstructure; primary aging at $1100^{\circ} \mathrm{C}$ for $1 \mathrm{~h}$ formed the aligned cubic $\gamma^{\prime}$ precipitates whereas that at $900^{\circ} \mathrm{C}$ for $96 \mathrm{~h}$ produced the random spherical $\gamma^{\prime}$ precipitates [24]. CMSX-2 also showed similar microstructures, i.e., aligned cubic $\gamma^{\prime}$ precipitates by primary aging at $1050^{\circ} \mathrm{C}$ for $16 \mathrm{~h}$ and at $980^{\circ} \mathrm{C}$ for $5 \mathrm{~h}$, which indicates that the lattice misfit becomes more negative at $1050^{\circ} \mathrm{C}$ than that at $980^{\circ} \mathrm{C}$ [15]. On the other hand, another Ni-based single crystal superalloy NASAIR100 has larger negative lattice misfit [29] than CMSX-2 [34], and thus it always shows aligned cubic $\gamma^{\prime}$ precipitates by primary aging from $980^{\circ} \mathrm{C}$ for $5 \mathrm{~h}$, to $1180{ }^{\circ} \mathrm{C}$ for $5 \mathrm{~h} \mathrm{[35].}$

\subsubsection{Morphology of Secondary $\gamma^{\prime}$ Precipitates}

As shown in Figure $6 \mathrm{a}, \mathrm{b}$, secondary $\gamma^{\prime}$ precipitates were clearly observed after primary aging at $1050^{\circ} \mathrm{C}$, while these secondary $\gamma^{\prime}$ precipitates did not grow even with increasing time. This indicates that these secondary $\gamma^{\prime}$ precipitates nucleated and grew during cooling from $1050{ }^{\circ} \mathrm{C}$. On the other hand, as shown in Figure $6 c, d$, the secondary $\gamma^{\prime}$ precipitates formed from the $950{ }^{\circ} \mathrm{C}$ aging are smaller (approximately $10 \mathrm{~nm}$ in diameter) than those precipitated from $1050{ }^{\circ} \mathrm{C}$ (approximately $40 \mathrm{~nm}$ in diameter). This indicates that growth of secondary $\gamma^{\prime}$ precipitates during cooling took place more rapidly from $1050{ }^{\circ} \mathrm{C}$ than from $950{ }^{\circ} \mathrm{C}$.

Formation of secondary $\gamma^{\prime}$ precipitates during cooling occurs from the supersaturated $\gamma$ matrix. In other words, it can be explained by the difference in equilibrium $\gamma^{\prime}$ volume fraction, which depends on temperature. Figure 7 shows simulated equilibrium phase fractions of the HESA as a function of temperature, derived from ThermoCalc using the TCNI8 database. Volume fraction of the $\gamma^{\prime}$ phase gradually decreases with increasing temperature, until it reaches the solvus of the $\gamma^{\prime}$ phase at $1161^{\circ} \mathrm{C}$. This shows that upon cooling, volume fraction of the $\gamma^{\prime}$ phase inevitably increases. The rapid cooling process after primary aging prefers the precipitation of fine secondary $\gamma^{\prime}$ particles from oversaturated $\gamma$ matrix rather than the growth of primary $\gamma^{\prime}$ precipitates.

During the aging treatment, the secondary $\gamma^{\prime}$ precipitates can either grow or dissolve into the $\gamma$ matrix, depending on aging temperature. As shown in Figure 6e, secondary $\gamma^{\prime}$ precipitates after aged at $800^{\circ} \mathrm{C}$ for $4 \mathrm{~h}$ are larger (approximately $40 \mathrm{~nm}$ in diameter) and more aggregated than those aged at 950 and $1050{ }^{\circ} \mathrm{C}$. This indicates that although not shown in Figure 2, some small secondary $\gamma^{\prime}$ precipitates had already formed during the cooling process after the Slope 1 solution heat treatment. Then, some remaining secondary $\gamma^{\prime}$ precipitates were coarsened and aggregated, and from there a multimodal size distribution of the $\gamma^{\prime}$ precipitates was observed by the $800{ }^{\circ} \mathrm{C}$ aging. After aging 
for $500 \mathrm{~h}$, the secondary $\gamma^{\prime}$ precipitates coarsened or merged into primary $\gamma^{\prime}$ precipitates, and then smaller secondary $\gamma^{\prime}$ precipitates with a size of approximately $10 \mathrm{~nm}$ in diameter were observed as shown in Figure $6 \mathrm{f}$, which are supposed to form during cooling after the $800^{\circ} \mathrm{C}$ aging. When aged at $950^{\circ} \mathrm{C}$ or above, the secondary $\gamma^{\prime}$ precipitates formed during cooling would rapidly dissolve into the $\gamma$ matrix or merge into primary $\gamma^{\prime}$ precipitates, due to lower equilibrium $\gamma^{\prime}$ volume fraction and higher diffusivity of solute elements. Thus, there will be no coarsened secondary $\gamma^{\prime}$ precipitates during the aging stage.

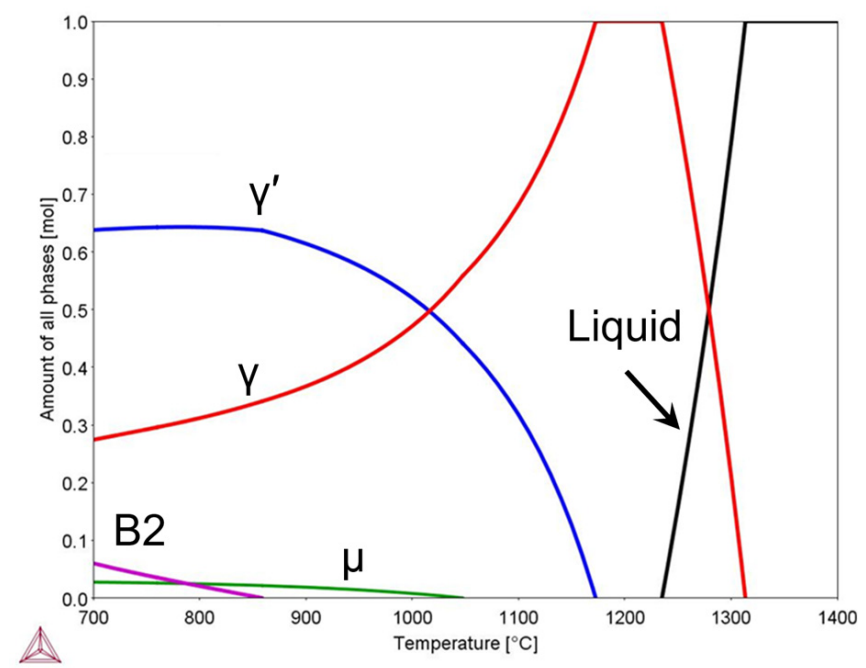

Figure 7. Equilibrium volume fraction of constituent phases of the high-entropy superalloy (HESA) simulated by ThermoCalc using TCNI8.

Through the microstructural investigation of primary aging, two contrastive types of microstructures were successfully obtained by controlling the heat treatment conditions, i.e., by the $S$ condition, where random distribution of spherical $\gamma^{\prime}$ precipitates were obtained, and by the $C$ condition, where aligned distribution of cubic $\gamma^{\prime}$ precipitates were obtained. These heat-treated samples are further subjected to the second step heat treatments.

\subsection{Secondary Aging Treatment}

Samples aged under $\mathrm{S}$ and $\mathrm{C}$ conditions were subjected to secondary aging treatments, whose conditions are 800,850 , and $870^{\circ} \mathrm{C}$ for $20 \mathrm{~h}$. Figure 8 shows the microstructure after secondary aging, and Figure 9 shows microstructure at higher magnified images of Figure 8, respectively.

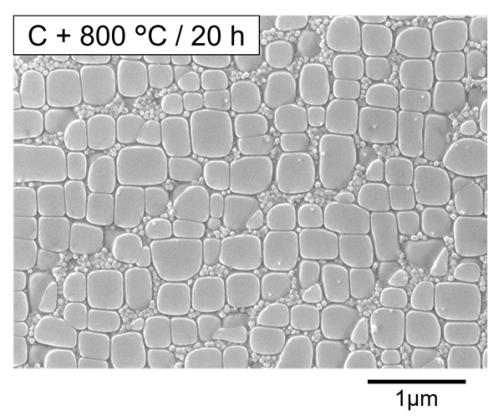

(a)

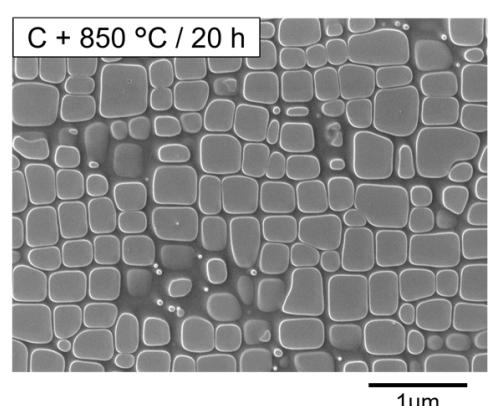

(b)

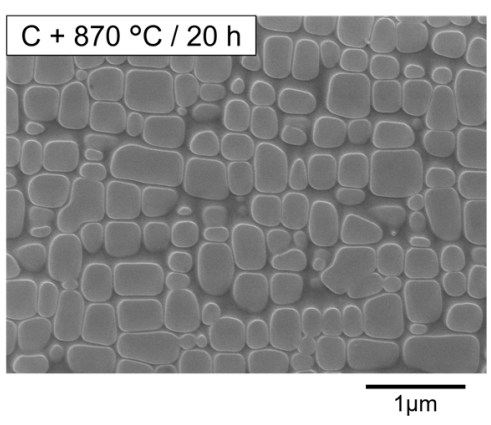

(c)

Figure 8. Cont. 


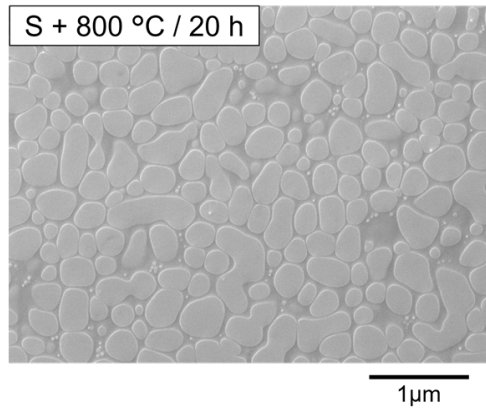

(d)

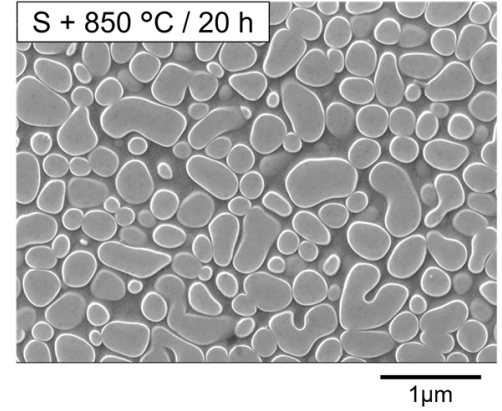

(e)

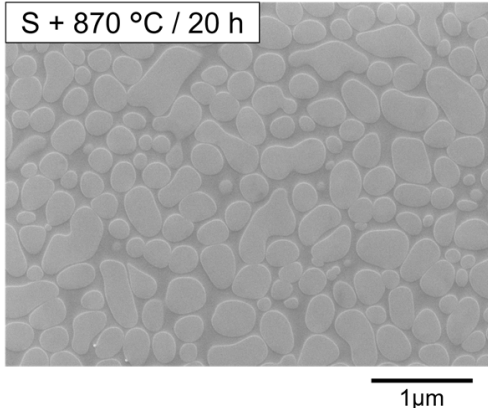

(f)

Figure 8. Microstructure after a series of secondary aging following Slope 1 solution treatment and primary aging in secondary electron images at the dendrite-core region. $(\mathbf{a}-\mathbf{c})$ Secondary aging following primary aging of $\mathrm{C}$ condition, (d-f) secondary aging following primary aging of $\mathrm{S}$ condition, $(\mathbf{a}, \mathbf{d})$ at $800{ }^{\circ} \mathrm{C}$ for $20 \mathrm{~h},(\mathbf{b}, \mathbf{e})$ at $850{ }^{\circ} \mathrm{C}$ for $20 \mathrm{~h},(\mathbf{c}, \mathbf{f})$ at $870^{\circ} \mathrm{C}$ for $20 \mathrm{~h}$ in secondary aging conditions.

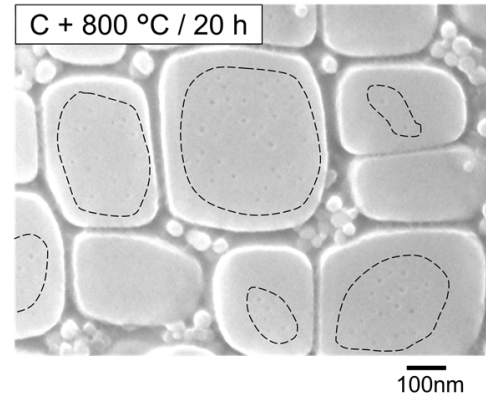

(a)

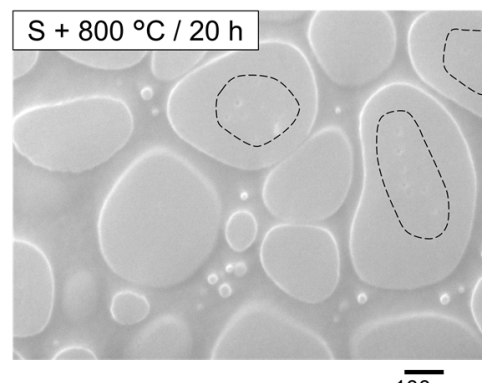

(d)

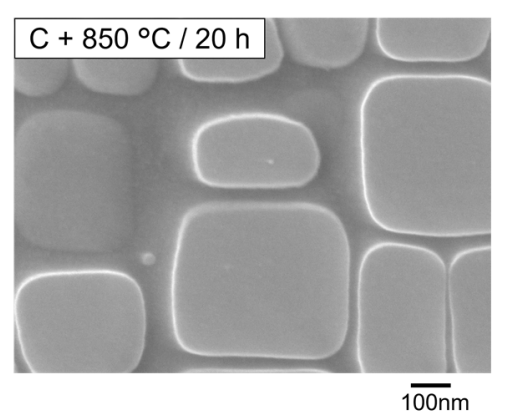

(b)

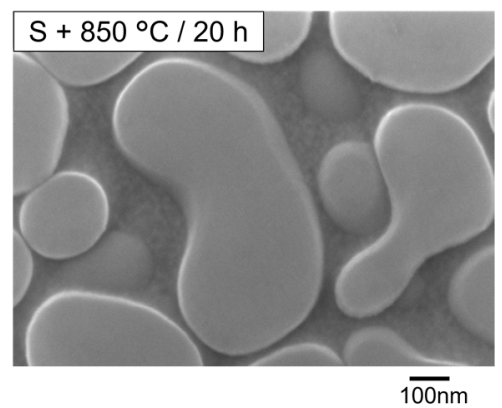

(e)

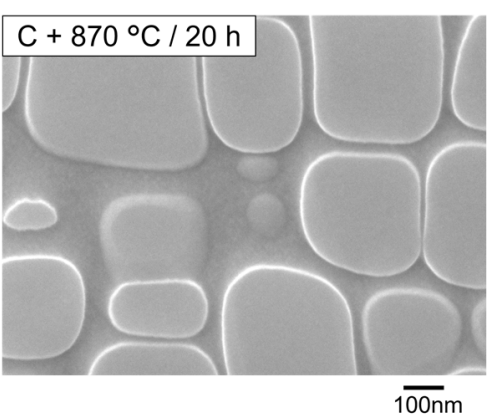

(c)

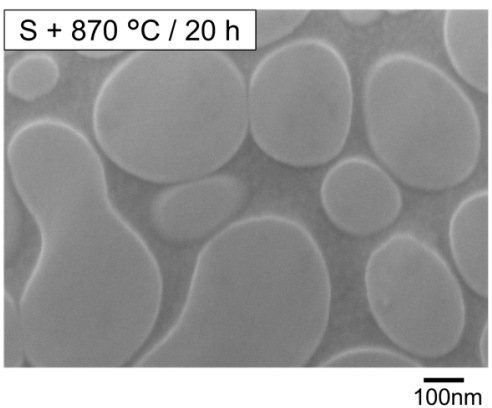

(f)

Figure 9. Secondary electron images at dendrite-core region with higher magnification. (a-c) Secondary aging following primary aging of $C$ condition, $(\mathbf{d}-\mathbf{f})$ secondary aging following primary aging of $S$ condition, (a,d) at $800^{\circ} \mathrm{C}$ for $20 \mathrm{~h},(\mathbf{b}, \mathbf{e})$ at $850{ }^{\circ} \mathrm{C}$ for $20 \mathrm{~h},(\mathbf{c}, \mathbf{f})$ at $870{ }^{\circ} \mathrm{C}$ for $20 \mathrm{~h}$ in secondary aging. The $\gamma$ nanoparticles are observed in the region surrounded by black dot loops $(\mathbf{a}, \mathbf{d})$.

Table 6 summarizes the microstructural features after secondary aging, focusing on primary $\gamma^{\prime}$ precipitates, secondary $\gamma^{\prime}$ precipitates, and nano $\gamma$ particles inside the primary $\gamma^{\prime}$ precipitates. 
Table 6. Summary of the microstructure after secondary aging following the Slope 1 solution treatment and the primary aging of $\mathrm{C}$ or $\mathrm{S}$ conditions.

\begin{tabular}{|c|c|c|c|c|}
\hline \multirow{2}{*}{ Primary Aging Condition } & \multirow{2}{*}{ Type of Phase } & \multicolumn{3}{|c|}{ Secondary Aging Condition } \\
\hline & & $800{ }^{\circ} \mathrm{C}$ for $20 \mathrm{~h}$ & $850{ }^{\circ} \mathrm{C}$ for $20 \mathrm{~h}$ & $870^{\circ} \mathrm{C}$ for $20 \mathrm{~h}$ \\
\hline \multirow{3}{*}{$\begin{array}{l}\text { C condition } \\
\left(1050^{\circ} \mathrm{C} \text { for } 4 \mathrm{~h}\right)\end{array}$} & $\begin{array}{l}\text { Primary } \gamma^{\prime} \\
\text { precipitates }\end{array}$ & \multicolumn{2}{|c|}{ Cube/aligned } & Transition/aligned \\
\hline & $\begin{array}{l}\text { Secondary } \gamma^{\prime} \\
\text { precipitates }\end{array}$ & Coarsened & \multicolumn{2}{|c|}{$\begin{array}{l}\text { Cooling (approximately } 10 \mathrm{~nm} \text { in } \\
\text { diameter) }\end{array}$} \\
\hline & $\begin{array}{l}\text { Nano } \gamma \\
\text { particles }\end{array}$ & Yes & \multicolumn{2}{|c|}{ No } \\
\hline \multirow{3}{*}{$\begin{array}{l}\text { S condition } \\
\left(950{ }^{\circ} \mathrm{C} \text { for } 20 \mathrm{~h}\right)\end{array}$} & $\begin{array}{l}\text { Primary } \gamma^{\prime} \\
\text { precipitates }\end{array}$ & \multicolumn{3}{|c|}{ Sphere/random } \\
\hline & $\begin{array}{l}\text { Secondary } \gamma^{\prime} \\
\text { precipitates }\end{array}$ & Coarsened & \multicolumn{2}{|c|}{$\begin{array}{c}\text { Cooling (approximately } 10 \mathrm{~nm} \text { in } \\
\text { diameter) }\end{array}$} \\
\hline & $\begin{array}{l}\text { Nano } \gamma \\
\text { particles }\end{array}$ & Yes & \multicolumn{2}{|c|}{ No } \\
\hline
\end{tabular}

\subsubsection{Morphology of Primary $\gamma^{\prime}$ Precipitates}

As shown in Figures $8 \mathrm{~d}-\mathrm{f}$ and $9 \mathrm{~d}-\mathrm{f}$, when aging is conducted under $\mathrm{S}$ condition, there are not significant differences observed in terms of size or shape of primary $\gamma^{\prime}$ precipitates by the secondary aging temperatures. On the other hand, the microstructures of samples aged under $\mathrm{C}$ condition change depending on the secondary heat treatment temperatures. For instance, when aged at $870{ }^{\circ} \mathrm{C}$ for $20 \mathrm{~h}$, corners of the primary $\gamma^{\prime}$ precipitates turn rounder as shown in Figure 9c. On the other hand, such clear changes were not observed when aged at 800 or $850^{\circ} \mathrm{C}$. As explained in Section 3.3, the lattice misfit between the $\gamma$ and $\gamma^{\prime}$ phases is supposed to be close to zero in the temperature range between 800 and $950{ }^{\circ} \mathrm{C}$, which could lead to the random distribution of spherical $\gamma^{\prime}$ precipitates under near equilibrium condition. Therefore, when secondary aging at $870{ }^{\circ} \mathrm{C}$ for $20 \mathrm{~h}$ is applied to the $\mathrm{C}$ conditioned samples, originally aligned cubic $\gamma^{\prime}$ precipitates could change its morphology more rapidly into randomly distributed spherical $\gamma^{\prime}$ precipitates, which is supposed to be an equilibrium microstructure between 800 and $950^{\circ} \mathrm{C}$, than those in secondary aging at 800 and $850{ }^{\circ} \mathrm{C}$ for $20 \mathrm{~h}$.

\subsubsection{Morphology of Secondary $\gamma^{\prime}$ Precipitates}

After secondary aging at $800^{\circ} \mathrm{C}$ for $20 \mathrm{~h}$, coarsened secondary $\gamma^{\prime}$ precipitates were observed in both $\mathrm{C}$ and $\mathrm{S}$ conditions, as shown in Figure $9 \mathrm{a}$,d. In a similar manner, as described in Section 3.3.2., these coarsened secondary $\gamma^{\prime}$ precipitates could have formed during the secondary aging process at $800^{\circ} \mathrm{C}$ from fine secondary $\gamma^{\prime}$ precipitates, which were formed during cooling from primary aging.

On the other hand, samples aged at 850 and $870{ }^{\circ} \mathrm{C}$ showed much smaller secondary $\gamma^{\prime}$ precipitates (as shown in Figure $9 b, c, e, f)$, confirming that the smaller secondary $\gamma^{\prime}$ precipitates (with size approximately $10 \mathrm{~nm}$ in diameter) formed during the cooling process after secondary aging treatment. It is also suggested that the secondary $\gamma^{\prime}$ precipitates, which formed during the cooling stage from primary aging, could grow at $800{ }^{\circ} \mathrm{C}$ or lower during secondary aging, while they dissolve into a $\gamma$ matrix or merge into the primary $\gamma^{\prime}$ precipitates more rapidly when aged at higher temperatures.

\subsubsection{Morphology of Nano $\gamma$ Particles}

It should be noted that after secondary aging at $800^{\circ} \mathrm{C}$ for $20 \mathrm{~h}$, the nano $\gamma$ particles inside the primary $\gamma^{\prime}$ precipitates were confirmed in both of $\mathrm{C}$ and $\mathrm{S}$ conditions. These nano $\gamma$ particles were not clearly observed by the primary aging treatment at $800{ }^{\circ} \mathrm{C}$. 


\section{Conclusions}

In this research, heat treatment and the microstructure relationship of a high-entropy superalloy (HESA) was systematically investigated; the heat treatments include solution treatment, primary, and secondary aging. The following conclusions can be drawn.

(1) In the as-cast stage, some extra phases were observed. Furthermore, coarsened $\gamma^{\prime}$ precipitates at the interdendrite region were found due to the microsegregation of constituent elements.

(2) Optimum solution treatment conditions to homogenize the microstructure by avoiding incipient melting was obtained. The solvus of $\gamma^{\prime}$ phase, the solidus, and the liquidus of the HESA were experimentally determined and were found to be lower than those of conventional Ni-based single crystal superalloys, SRR99, CMSX-2, CMSX-4, and CMSX-10.

(3) In the primary aging, the morphology of $\gamma^{\prime}$ precipitates changed depending on the aging temperature. When aged below $950{ }^{\circ} \mathrm{C}$, randomly distributed spherical $\gamma^{\prime}$ precipitates formed, while at $1050^{\circ} \mathrm{C}$, aligned cubic $\gamma^{\prime}$ precipitates formed. This indicates that the lattice misfit between $\gamma$ and $\gamma^{\prime}$ phases goes from near zero to negative when the temperature rises from 950 to $1050{ }^{\circ} \mathrm{C}$.

(4) At $800{ }^{\circ} \mathrm{C}$ for $20 \mathrm{~h}$ in secondary aging, coarsened secondary $\gamma^{\prime}$ precipitates and nano $\gamma$ particles inside primary $\gamma^{\prime}$ precipitates were found. Coarsened secondary $\gamma^{\prime}$ precipitates were formed during secondary aging at $800{ }^{\circ} \mathrm{C}$ from the finer secondary $\gamma^{\prime}$ precipitates that formed during cooling from primary aging. After secondary aging at 850 and $870{ }^{\circ} \mathrm{C}$ for $20 \mathrm{~h}$, much smaller secondary $\gamma^{\prime}$ precipitates, which formed during cooling from secondary aging, were found instead of coarsened secondary $\gamma^{\prime}$ precipitates.

In the present study, a variety of microstructures was obtained by systematic heat treatments, and their formation mechanism was discussed. In particular, two contrastive morphologies of primary $\gamma^{\prime}$ precipitates, i.e., aligned distribution of cubic $\gamma^{\prime}$ precipitates and random distribution of spherical $\gamma^{\prime}$ precipitates, were obtained. By using these heat treatments, investigation of the relationship between microstructure and mechanical properties should be conducted, which will be introduced in the near future.

Author Contributions: Conceptualization, T.S., A.-C.Y., and H.M.; data curation, T.S. and Y.-T.C.; formal analysis, W.-C.H.; funding acquisition, H.M.; investigation, T.S. and Y.-T.C.; methodology, Y.T. and K.K.; supervision, H.M.; writing-original draft, T.S.; writing-review and editing, A.-C.Y. and H.M. All authors have read and agreed to the published version of the manuscript.

Funding: This research received no external funding.

Acknowledgments: The authors would like to thank Masahiko Kawasaki in the National Institute for Materials Science (NIMS) for facilitating quart glass tubes including samples; Mitsuo Nishio in NIMS for conducting the EPMA; Akira Ishitoya in NIMS for conducting ICP-OES; and Akira Ishida and Makoto Osawa in NIMS for the constructive discussion.

Conflicts of Interest: The authors declare no conflict of interest.

\section{References}

1. Yeh, J.-W.; Chen, S.-K.; Lin, S.-J.; Gan, J.-Y.; Chin, T.-S.; Shun, T.-T.; Tsau, C.-H.; Chang, S.-Y. Nanostructured High-Entropy Alloys with Multiple Principal Elements: Novel Alloy Design Concepts and Outcomes. Adv. Eng. Mater. 2004, 6, 299-303. [CrossRef]

2. Cantor, B.; Chang, I.T.H.; Knight, P.; Vincent, A.J.B. Microstructural development in equiatomic multicomponent alloys. Mat. Sci. Eng. A 2004, 375-377, 213-218. [CrossRef]

3. Wu, Z.; Bei, H.; Pharr, G.M.; George, E.P. Temperature dependence of the mechanical properties of equiatomic solid solution alloys with face-centered cubic crystal structures. Acta Mater. 2014, 81, 428-441. [CrossRef]

4. Otto, F.; Dlouhý, A.; Somsen, C.; Bei, H.; Eggeler, G.; George, E.P. The influence of temperature and microstructure on the tensile properties of a CoCrFeMnNi high-entropy alloy. Acta Mater. 2013, 5743-5755. [CrossRef]

5. Gludovatz, B.; Hohenwarter, A.; Catoor, D.; Chang, E.H.; George, E.P.; Ritchie, R.O. A fracture-resistant high-entropy alloy for cryogenic applications. Science 2014, 345, 1153-1158. [CrossRef] 
6. Ro, Y.; Koizumi, Y.; Harada, H. High temperature tensile properties of a series of nickel-base superalloys on a $\gamma / \gamma^{\prime}$ tie line. Mater. Sci. Eng. A 1997, 223, 59-63. [CrossRef]

7. Murakumo, T.; Koizumi, Y.; Kobayashi, K.; Harada, H. Creep strength of Ni-base single-crystal superalloys on the $\gamma / \gamma^{\prime}$ tie-line. In Proceedings of the Tenth International Symposium on Superaloys (Superalloys 2004), Champion, PA, USA, 19-23 September 2004; pp. 155-162. [CrossRef]

8. Yeh, A.-C.; Chang, Y.-J.; Tsai, C.-W.; Wang, Y.-C.; Yeh, J.-W.; Kuo, C.-M. On the Solidification and Phase Stability of a Co-Cr-Fe-Ni-Ti High-Entropy Alloy. Metall. Mat. Trans. A 2014, 45, 184-190. [CrossRef]

9. Chuang, M.H.; Tsai, M.H.; Wang, W.R.; Lin, S.J.; Yeh, J.W. Microstructure and wear behavior of $\mathrm{Al}_{\mathrm{x}} \mathrm{Co}_{1.5} \mathrm{CrFeN}_{1.5} \mathrm{Ti}_{\mathrm{y}}$ high-entropy alloys. Acta Mater. 2011, 59, 6308-6317. [CrossRef]

10. Tong, C.J.; Chen, Y.L.; Yeh, J.W.; Lin, S.J.; Chen, S.K.; Shun, S.K.; Tsau, C.H.; Chang, S.Y. Microstructure characterization of $\mathrm{Al}_{x} \mathrm{CoCrCuFeNi}$ high-entropy alloy system with multiprincipal elements. Metall. Mater. Trans. A 2005, 36, 881-893. [CrossRef]

11. Chen, Y.T.; Chang, Y.J.; Muraami, H.; Gorsse, S.; Yeh, A.C. Designing high entropy superalloys for elevated temperature application. Scr. Mater. 2020, 187, 177-182. [CrossRef]

12. Yeh, J.W. Alloy design strategies and future trends in high-entropy alloys. JOM 2013, 6, 1759-1771. [CrossRef]

13. Tsao, T.-K.; Yeh, A.-C.; Kuo, C.-M.; Kakehi, K.; Murakami, H.; Yeh, J.-W.; Jian, S.-R. The High Temperature Tensile and Creep Behaviors of High Entropy Superalloy. Sci. Rep. 2017, 7, 12658. [CrossRef] [PubMed]

14. Kobayashi, T.; Harada, H.; Zhang, J. Influence of heat treatment on microstructure and mechanical properties of 1st generation single-crystal superalloy. J. Japan Inst. Metals 2006, 70, 47-50. [CrossRef]

15. Caron, P.; Khan, T. Improvement of Creep strength in a nickel-base single-crystal superalloy by heat treatment. Mater. Sci. Eng. A 1983, 61, 173-184. [CrossRef]

16. Reppich, B.; Schepp, P.; Wehner, G. Some new aspects concerning particle hardening mechanisms in $\gamma^{\prime}$ precipitating nickel-base alloys-II. Experiments. Acta Metall. 1982, 30, 95-104. [CrossRef]

17. Reppich, B. Some new aspects concerning particle hardening mechanisms in $\gamma^{\prime}$ precipitating Ni-base alloy- 1 . Theoretical concept. Acta Metall. 1982, 1, 87-94. [CrossRef]

18. Zhou, N.; Shen, C.; Mills, M.J.; Li, J.; Wang, Y. Modeling displacive-diffusional coupled dislocation shearing of $\gamma^{\prime}$ precipitates in Ni-base superalloys. Acta Mater. 2011, 59, 3484-3497. [CrossRef]

19. Feng, L.; Lv, D.; Rhein, R.K.; Goiri, J.G.; Titus, M.S.; Van der Ven, A.; Pollock, T.M.; Wang, Y. Shearing of $\gamma^{\prime}$ particles in Co-base and Co-Ni-base superalloys. Acta Mater. 2018, 161, 99-109. [CrossRef]

20. Tsao, T.-K.; Yeh, A.-C.; Yeh, J.-W.; Chiou, M.-S.; Kuo, C.-M.; Murakami, H.; Kakehi, K. High Temperature Properties of Advanced Directionally-Solidified High Entropy Superalloys. In Proceedings of the Seventh International Symposium on Superalloys (Superalloys 2016), Champion, PA, USA, 11-15 September 2016; pp. 1002-1009. [CrossRef]

21. Chen, Y.-T.; Chang, Y.-J.; Murakami, H.; Sasaki, T.; Hono, K.; Li, C.-W.; Kakehi, K.; Yeh, J.-W.; Yeh, A.-C. Hierarchical microstructure strengthening in a single crystal high entropy superalloy. Sci. Rep. 2020, 10, 12163. [CrossRef]

22. Hegde, S.R.; Kearsey, R.M.; Beddoes, J.C. Designing homogenization-solution heat treatments for single crystal superalloys. Mater. Sci. Eng. A 2010, 527, 5528-5538. [CrossRef]

23. Pang, H.T.; D'Souza, N.; Dong, H.; Stone, H.J.; Rae, C.M.F. Detailed Analysis of the Solution Heat Treatment of a Third-Generation Single-Crystal Nickel-Based Superalloy CMSX-10K ${ }^{\circledR}$. Metall. Mat. Trans. A 2016, 47, 889-906. [CrossRef]

24. Hopgood, A.A.; Martin, J.W. Coarsening of $\gamma^{\prime}$-precipitates in single-crystal superalloy SRR 99. Mater. Sci. Technol. 1986, 2, 543-546. [CrossRef]

25. Harris, K.; Erickson, G.L.; Schwer, R.E. MAR M 247 derivations-CM 247 LC DS alloy CMSX single crystal alloys properties and performance. In Proceedings of the Fifth International Symposium on Superalloys (Superalloys 1984), Champion, PA, USA, 7-11 October 1984; pp. 221-230. [CrossRef]

26. Harris, K.; Erickson, G.L.; Sikkenga, S.L.; Brentnall, W.D.; Aurrecoechea, J.M.; Kubarych, K.G. Development of the Rhenium Containing Superalloy CMSX-4 for Single Crystal Blade Applications in Advanced Turbine Engines. In Proceedings of the Seventh International Symposium on Superalloys (Superalloys 1992), Champion, PA, USA, 20-24 September 1992; pp. 20-24. [CrossRef]

27. Erickson, G.L. The development and application of CMSX-10. In Proceedings of the Eighth International Symposium on Superalloys (Superalloys 1996), Champion, PA, USA, 22-26 September 1996; pp. 35-44. [CrossRef] 
28. Doi, M.; Miyazaki, T. The effect of elastic interaction energy on the shape. In Proceedings of the Fifth International Symposium on Superalloys (Superalloys 1984), Champion, PA, USA, 7-11 October 1984; pp. 543-552.

29. Nathal, M.V.; Mackay, R.A.; Garlick, R.G. Temperature dependence of $\gamma-\gamma^{\prime}$ lattice mismatch in Nickel-base superalloys. Mater. Sci. Eng. 1985, 75, 195-205. [CrossRef]

30. Johnson, W.C.; Voorhees, P.W. Elastic interaction and stability of misfitting cuboidal inhomogeneities. J. Appl. Phys. 1987, 61, 1610-1619. [CrossRef]

31. Epishin, A.; Link, T.; Nolze, G. SEM investigation of interfacial dislocations in nickel-base superalloys. J. Microsc. 2007, 228, 110-117. [CrossRef] [PubMed]

32. Véron, M.; Bréchet, Y.; Louchet, F. Strain induced directional coarsening in Ni based superalloys. Scr. Mater. 1996, 34, 1883-1886. [CrossRef]

33. Matan, N.; Cox, D.C.; Rae, C.M.F.; Reed, R.C. On the kinetics of rafting in CMSX-4 superalloy single crystals. Acta Mater. 1999, 47, 2013-2045. [CrossRef]

34. Fredholm, A.; Strudel, J.L. On the creep resistance of some nickel base single crystals. In Proceedings of the Fifth International Symposium on Superalloys (Superalloys 1984), Champion, PA, USA, 7-11 October 1984; pp. 211-220. [CrossRef]

35. Ohno, T.; Watanabe, R.; Yoshinari, A. Effect of aging heat-treatment condition on creep-rupture strength of Nickel-base single crystal superalloys. Tetsu-to-Hagané 1989, 75, 964-971. [CrossRef]

Publisher's Note: MDPI stays neutral with regard to jurisdictional claims in published maps and institutional affiliations. 